\title{
Effect of fetal hemoglobin on microvascular regulation in sickle transgenic-knockout mice
}

\author{
Dhananjay K. Kaul, Xiao-du Liu, Hee-Yoon Chang, Ronald L. Nagel, and Mary E. Fabry \\ Division of Hematology, Department of Medicine, Albert Einstein College of Medicine, Bronx, New York, USA.
}

\begin{abstract}
In sickle cell disease, intravascular sickling and attendant flow abnormalities underlie the chronic inflammation and vascular endothelial abnormalities. However, the relationship between sickling and vascular tone is not well understood. We hypothesized that sickling-induced vaso-occlusive events and attendant oxidative stress will affect microvascular regulatory mechanisms. In the present studies, we have examined whether microvascular abnormalities expressed in sickle transgenic-knockout Berkeley (BERK) mice (which express exclusively human $\alpha$-and $\beta^{\mathrm{S}}$-globins with $<1 \% \gamma$-globin levels) are amenable to correction with increased levels of antisickling fetal hemoglobin (HbF). In BERK mice, sickling, increased oxidative stress, and hemolytic anemia are accompanied by vasodilation, compensatory increases in eNOS and COX-2, and attenuated vascular responses to NO-mediated vasoactive stimuli and norepinephrine. The hypotension and vasodilation (required for adequate oxygen delivery in the face of chronic anemia) are mediated by non-NO vasodilators (i.e., prostacyclin) as evidenced by induction of COX-2. In BERK mice, the resistance to NO-mediated vasodilators is associated with increased oxidative stress and hemolytic rate, and in BERK $+\gamma$ mice (expressing $20 \% \mathrm{HbF}$ ), an improved response to these stimuli is associated with reduced oxidative stress and hemolytic rate. Furthermore, BERK $+\gamma$ mice show normalization of vessel diameters, and eNOS and COX-2 expression. These results demonstrate a strong relationship between sickling and microvascular function in sickle cell disease.
\end{abstract}

\section{Introduction}

Sickle cell disease is characterized by recurring episodes of painful vaso-occlusive crisis, acute chest syndrome, and multiple organ damage. Although hemoglobin S (HbS) polymerization and red cell sickling under deoxygenated conditions are central to the pathophysiology of this disease, emerging evidence indicates that vascular endothelial activation and blood cell-endothelium interactions may contribute significantly to the onset of vaso-occlusive episodes. Vascular endothelial abnormalities may result from intravascular sickling and red cell-endothelium interaction, as well as from reperfusion injury involving transient occlusive events (1-3). Human sickle cell disease patients show chronic inflammation as evidenced by elevated cytokines, endothelial cell damage, endothelial cell detachment, and increased leukocyte counts (4-9).

Recent studies have revealed that intravascular sickling is the causative factor in hypoxia/reoxygenation-induced endothelial oxidant generation in transgenic sickle mice (3). In fact, both sickle cell disease patients and transgenic-knockout sickle mice show increased oxidant production under steady-state conditions (10). The rheological abnormalities of sickle red cells and the associated transient occlusive events may not only contribute to inflammation but also affect vasoregulatory function of vascular endothelium as in other inflammatory diseases (11).

Vascular tone alterations in sickle cell disease are indicated by reports of lower peripheral resistance (12), intermittent periodic

Nonstandard abbreviations used: ACh, acetylcholine; BERK, Berkeley; BERK-trait, BERK trait L; $D$, vessel luminal diameter; $\mathrm{DAB}, 3,3^{\prime}$-diaminobenzidine; HbF, fetal hemoglobin; HbS, hemoglobin S; L-NAME, nitro-L-arginine methylester; MAP, mean arterial pressure; $\mathrm{MCH}$, mean corpuscular hemoglobin; NE, norepinephrine; NOS, NO synthase; $Q$, volumetric flow rate; SNP, sodium nitroprusside; $\beta$-thal, $\beta$-thalassemic; $V_{\text {mean }}$, mean $V_{\mathrm{rbc}} ; V_{\mathrm{rbc}}$, red cell velocity.

Conflict of interest: The authors have declared that no conflict of interest exists.

Citation for this article: J. Clin. Invest. 114:1136-1145 (2004).

doi:10.1172/JCI200421633 microcirculatory flow (13), depressed vasomotor response following postocclusive hyperemia (14), impaired NO bioavailability (15), and attenuated vascular response to oxygen $(16,17)$. Impaired NO bioavailability in this disorder is indicated by blunted response to endothelium-dependent vasodilators in sickle mouse models $(10,18,19)$, as well as by a reduced flow-mediated vasodilation in human sickle cell disease patients $(20,21)$. In human sickle cell disease patients, however, plethysmographic measurements of forearm blood flow show a greater vasodilatory response (i.e., increase in blood flow) to acetylcholine (ACh), an endothelium-dependent vasodilator, as compared with normal subjects $(16,20)$. The increased blood flow response to ACh may involve upregulation of non-NO vasodilators (20), although this aspect has not been explored. On the other hand, sodium nitroprusside (SNP), an NO donor, causes comparable increases in forearm blood flow in sickle cell disease patients and normal individuals. However, the responses to both ACh and SNP are reduced in male sickle cell disease patients (20). Also, patients with increased hemolytic rate show a diminished response to SNP (15), which suggests that hemolysis in this disease would limit NO bioavailability, since NO is consumed by ferrous hemoglobin.

The present intravital studies were designed to examine the potential role of $\mathrm{NO}$ and non-NO vasodilatory mechanisms in the regulation of microvascular flow in this disease. Because vascular resistance to blood flow is mainly determined by the vascular tone of arterioles (resistance vessels) in the microcirculation, it is important to determine the mechanisms affecting the arteriolar tone in the above context. In contrast to large conduit arteries, arterioles are uniquely endowed with the ability to undergo vasomotion (i.e., rhythmic contraction and dilation of vessel diameter). The abnormalities of arteriolar tone may contribute significantly to vaso-occlusive events. In the present studies, we address the relationship between sickling, vascular tone, and microvascular flow. 
Table 1

Hematological parameters in controls and knockout sickle mice

$\alpha^{H}$, human $\alpha$-globin; $\beta^{S}$, human $\beta^{S}$-globin; $\gamma$, human $\gamma$-globin; retics, reticulocytes. ANumber of mice used in these measurements: C57BL/6J, 20; C57BL $\beta$-thal, 6; BERK-trait, 4; BERK, 20; BERK + $\gamma, 5$. Reticulocytes and plasma hemoglobin determinations were done in $7 \beta$-thal mice and in 5 mice from each of the other genotypes. ${ }^{B} P<0.05-0.0000001$ vs. C57BL controls. ${ }^{C} P<0.034-0.001$ vs. BERK mice.

$\begin{array}{lccccccc}\text { Mouse } & \alpha^{\mathrm{H}} & \beta^{\mathrm{S}} & \gamma & \begin{array}{c}\text { Hematocrit } \\ (\%)\end{array} & \begin{array}{c}\text { MCH } \\ (\mathbf{p g} / \mathbf{c e l l})^{\mathrm{A}}\end{array} & \begin{array}{c}\text { Retics } \\ (\%)\end{array} & \begin{array}{c}\text { Plasma hemoglobin } \\ (\mu \mathrm{mol} \text { heme) }\end{array} \\ \text { C57BL/6J } & 0 & 0 & 0 & 48 \pm 1 & 14.5 \pm 1.0 & 1.4 \pm 0.4 & 3.0 \pm 0.5 \\ \text { C57BL } \beta \text {-thal } & 0 & 0 & 0 & 32.3 \pm 1.6^{\mathrm{B}} & 12.7 \pm 0.5 & 23.8 \pm 2.6^{\mathrm{B}} & 4.4 \pm 1.5 \\ \text { BERK-trait } & 100 & 15 & <1 & 41.0 \pm 2.3^{\mathrm{B}} & 13.1 \pm 0.5 & 7.8 \pm 1.5^{\mathrm{B}} & 3.4 \pm 1.3 \\ \text { BERK } & 100 & >99 & <1 & 28.7 \pm 4.0^{\mathrm{B}} & 9.3 \pm 0.8^{\mathrm{B}} & 39.5 \pm 4.3^{\mathrm{B}} & 7.6 \pm 1.2^{\mathrm{B}} \\ \text { BERK }+\gamma & 100 & 79 & 21 & 41.6 \pm 4.0^{\mathrm{B}, \mathrm{C}} & 10.8 \pm 1.3^{\mathrm{B}} & 31.9 \pm 4.2^{\mathrm{B}, \mathrm{C}} & 5.6 \pm 1.0^{\mathrm{B}, \mathrm{C}}\end{array}$

respectively). BERK $+\gamma$ mice expressing $20 \% \gamma$-globin levels showed increased MCH $(10.8 \pm 1.3 \mathrm{pg} /$ cell $)$ compared with BERK mice. As previously described, BERK $+\gamma$ mice have heterogeneous expression of $\mathrm{HbF}$. Some red cells have high levels of $\mathrm{HbF}$ (F cells) and some have none (24). This heterogeneous distribution of $\mathrm{HbF}$ is reminiscent of that in human sickle cell disease patients (25).

The low hematocrit level in BERK mice $(28.7 \% \pm 4.0 \%$ vs. $48 \% \pm 1.0 \%$ for C $57 \mathrm{BL}$ mice) was associated with high reticulocyte counts $(39.5 \% \pm 4.3 \%$ vs. $1.4 \% \pm 0.4 \%$ for C57BL) and increased plasma hemoglobin levels expressed as micromoles of
Therapeutic strategies to prevent sickling include increasing the levels of antisickling fetal hemoglobin ( $\mathrm{HbF}$ ) by hydroxyurea therapy (22), as well as reducing the mean corpuscular hemoglobin $(\mathrm{MCH})$ concentration (23). In the presence of $\mathrm{HbF}\left(\alpha_{2} \gamma_{2}\right)$, polymer formation is efficiently prevented (24). $\mathrm{HbF}$ exerts an ameliorating effect in sickle cell disease patients both on red cells and in prevention of multiple organ damage, and a recent study has shown that hydroxyurea therapy increases responsiveness to SNP (20). However, the impact of $\mathrm{HbF}$ on microvascular flow regulation has not been explored. The availability of transgenic-knockout sickle mice expressing human $\alpha$ - and $\beta^{\mathrm{S}}$-globins with varying levels of $\mathrm{HbF}(24)$ provides an opportunity to determine the relationship between intravascular sickling and microvascular abnormalities.

We hypothesize that sickling-induced transient occlusive episodes and increased oxidative stress will result in microvascular regulatory abnormalities, and that inhibition of sickling by an increase in $\mathrm{HbF}$ will tend to ameliorate these abnormalities. Here, we show that microcirculatory abnormalities and greatly impaired vascular reactivity in transgenic-knockout Berkeley (BERK) mice (which express exclusively human $\alpha$ - and $\beta^{\mathrm{S}}$-globins with very low levels of $\gamma$-globin $[<1 \%])$ are associated with increased oxidative stress, sickling, hemolytic anemia, and a reduced NO bioavailability. The compensatory responses in this mouse model include induction of COX-2 and upregulation of eNOS, both vasodilator species. Furthermore, increasing the level of antisickling $\mathrm{HbF}$ in this mouse model results in significant alleviation of hemolytic anemia, oxidative stress, and vascular tone abnormalities.

\section{Results}

\section{Hematological parameters}

Table 1 presents hematological features of mice used in these studies. As is evident, BERK mice showed thalassemic characteristics, i.e., globin chain imbalance ( $\beta$-globin: $\alpha$-globin ratio, $0.79)$ that is similar to that reported in $\beta$-thalassemic ( $\beta$-thal) mice, while in $\mathrm{C} 57 \mathrm{BL} / 6 \mathrm{~J}$ mice (also called C57BL mice), the $\beta: \alpha$ ratio approached 0.93 (24). Consistent with thalassemic features, BERK mice showed a low $\mathrm{MCH}$ compared with control C57BL mice $(9.3 \pm 0.8$ and $14.5 \pm 1.0 \mathrm{pg} /$ cell,

Table 2 heme (7.6 \pm 1.2 vs. $3.0 \pm 0.5$ for C57BL, $P<0.00001)$; these associations indicate increased red cell destruction. Plasma hemoglobin levels in control mice were comparable to those reported previously (26). While BERK $+\gamma$ mice showed an increase in hematocrit $(41.6 \% \pm 4.0 \%)$ as compared with BERK mice, reticulocyte counts showed only a slight but significant decrease to $31.9 \% \pm 4.2 \%(P<0.01)$. While anemia was significantly corrected in BERK $+\gamma$ mice, plasma hemoglobin levels $(5.6 \pm 1.0 \mu \mathrm{mol})$, although lower than in BERK mice $(P<0.034)$, remained higher than in C57BL mice $(P<0.002)$, indicating persistence of hemolysis. The reticulocyte counts compared favorably with those previously reported (24). On the other hand, in $\beta$-thal mice, low hematocrit was associated with increased reticulocyte counts $(23.8 \% \pm 2.6 \%)$ but no significant increase in plasma hemoglobin levels $(4.4 \pm 1.5 \mu \mathrm{mol})$ as compared with C57BL mice, which is consistent with anemia associated with destruction of red cells in the reticuloendothelial system and/or inefficient erythropoiesis in human $\beta$-thalassemia.

\section{Hemodynamic parameters in BERK mice}

We compared hemodynamic and microvascular parameters in BERK mice with those in C57BL controls, $\beta$-thal mice, and BERK trait L (BERK-trait) mice. We used $\beta$-thal mice as additional controls because BERK mice show thalassemic characteristics.

Mean arterial blood pressure. The averaged mean arterial pressure (MAP) values in BERK mice $(n=13)$ showed a pronounced decrease compared with those in C57BL $(n=17), \beta$-thal $(n=4)$, and BERK-
Resting microvascular diameters $(\mu \mathrm{m})$ in C57BL, $\beta$-thal, BERK-trait, BERK, and BERK $+\gamma$ mice

\begin{tabular}{|c|c|c|c|c|c|}
\hline Vessel order & r C57BL & $\beta$-thal & BERK-trait & BERK & BERK $+\gamma$ \\
\hline \multicolumn{6}{|l|}{ Arterioles } \\
\hline $\begin{array}{l}\text { A2 } \\
\text { A3 } \\
\text { A4 }\end{array}$ & $\begin{array}{l}45.8 \pm 2.7(8) \\
23.0 \pm 0.9(15) \\
13.9 \pm 1.1(8)\end{array}$ & $\begin{array}{l}44.1 \pm 2.9(5) \\
22.2 \pm 1.2(12) \\
14.3 \pm 0.9(10)\end{array}$ & $\begin{array}{l}45.2 \pm 2.4(9) \\
20.7 \pm 1.1(11) \\
14.7 \pm 0.7(8)\end{array}$ & $\begin{array}{l}63.5 \pm 2.3(12)^{A} \\
32.5 \pm 1.4(23)^{A} \\
19.1 \pm 0.7(24)^{A}\end{array}$ & $\begin{array}{l}47.3 \pm 1.8(8)^{\mathrm{A}} \\
22.1 \pm 1.9(7)^{\mathrm{A}} \\
14.7 \pm 3.7(6)^{\mathrm{A}}\end{array}$ \\
\hline \multicolumn{6}{|l|}{ Venules } \\
\hline $\begin{array}{l}\text { V2 } \\
\text { V3 } \\
\text { V4 }\end{array}$ & $\begin{array}{l}63.4 \pm 2.8(8) \\
33.1 \pm 1.8(9) \\
17.2 \pm 0.7(9)\end{array}$ & $\begin{array}{l}60.7 \pm 4.5(5) \\
33.0 \pm 2.7(12) \\
18.0 \pm 1.0(11)\end{array}$ & $\begin{array}{l}62.0 \pm 1.7(8) \\
32.9 \pm 1.1(10) \\
20.9 \pm 1.3(7)\end{array}$ & $\begin{array}{l}73.2 \pm 2.6(10)^{\mathrm{A}} \\
39.2 \pm 1.8(19) \\
23.1 \pm 1.0(16)^{\mathrm{B}}\end{array}$ & $\begin{array}{l}61.0 \pm 1.5(7)^{A} \\
29.1 \pm 1.3(10)^{A} \\
17.0 \pm 0.3(6)^{A}\end{array}$ \\
\hline
\end{tabular}

Values are mean $\pm \mathrm{SEM}$; the numbers in parentheses represent the number of vessels. Number of mice used in these measurements: C57BL, 6 ; $\beta$-thal, 3; BERK-trait, 4; BERK, 10 ; BERK + $\gamma$, 4 . If the average for each animal is calculated and these values are averaged, the resulting values are not significantly different from those presented. ${ }^{A} P<0.05$ vs. other groups; ${ }^{B} P<0.05$ vs. $C 57 B L$ and $\beta$-thal mice. 


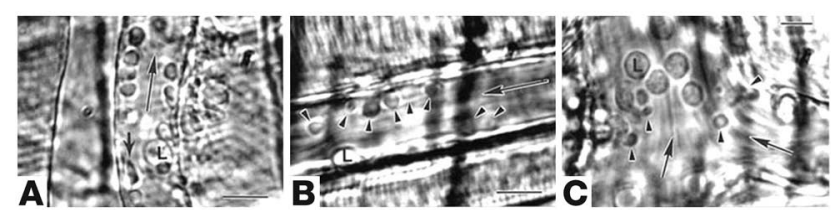

Figure 1

Videomicrographs showing in vivo adhesion of red cells to endothelium of postcapillary venules in the cremaster muscle microcirculation of the BERK mouse. (A) Adherent red cells and a leukocyte (L) during flow (large arrow). The small arrow indicates an irreversibly sickled cell. Scale bar: $15 \mu \mathrm{m}$. (B) Adherent red cells (arrowheads) in a postcapillary venule during flow (large arrow). Scale bar: $15 \mu \mathrm{m}$. (C) Adherent red cells (arrowheads) and large-diameter leukocytes $(L)$ at the confluence of postcapillary venules during flow (large arrow). Scale bar: $10 \mu \mathrm{m}$.

trait $(n=4)$ mice $(P<0.05$, multiple comparisons by ANOVA). The averaged MAP in BERK mice showed an average reduction of approximately $40 \mathrm{mmHg}$ compared with that in C57BL mice $(65.2 \pm 2.4$ vs. $104.6 \pm 1.7 \mathrm{mmHg})$, while $\beta$-thal and BERK-trait mice showed intermediate MAP values $(91.3 \pm 4.3$ and $91.3 \pm 3.2$ $\mathrm{mmHg}$, respectively).

Vessel diameters and microvascular flow characteristics. Systemic hypotension in BERK mice was associated with about 40\% dilation of the resistance vessels (arteriolar branching orders A2, A3, and A4) and about $15 \%$ dilation of V2 venules in the cremaster muscle microcirculation $(P<0.05)$ compared with those in C57BL control mice (Table 2). No significant differences in vessel diameters were noted among control groups (C57BL, $\beta$-thal, and BERK-trait mice).

Direct microscopic observations and videoanalysis of the microvascular flow under resting conditions in the cremaster muscle preparation in BERK mice revealed frequent red cell adhesion in postcapillary venules (Figure 1, A-C). Red cells with sickle morphology (probably irreversibly sickled cells in addition to elongated sickled cells) were also observed (Figure 1B). Intravascular sickling was observed in postcapillary venules as well as in terminal arterioles, often resulting in stasis. We also found increased leukocyte-endothelium interactions (Figure 1C), indicating a proinflammatory condition, in BERK mice. This is in accord with the observations of Turhan el al. (27), who showed increased leukocyte recruitment (as well as red cell-leukocyte interaction) in the cremaster venules of C57BL mice transplanted with bone marrow derived from BERK mice.

Next, we investigated the impact of red cell adhesion and intravascular sickling on red cell velocity $\left(V_{\mathrm{rbc}}\right)$, wall shear rate, and volumetric flow rate $(Q)$ in similar branching orders of arterioles (A2-A4) and venules (V2-V4) in BERK mice (see Methods). Arteriolar $V_{\mathrm{rbc}}$ (in $\mathrm{mm} / \mathrm{s}$, mean $\pm \mathrm{SE}$ ) was somewhat lower in BERK mice $(n=8)$, showing significant differences $(P<0.05)$ for A2 arterioles compared with those of control C57BL mice $(n=6)$ (Figure 2A). Wall shear rates $\left(\mathrm{s}^{-1}\right)$, calculated from vessel diameter and mean

\section{Figure 2}

Arteriovenous $V_{\mathrm{rbc}}(\mathbf{A})$, wall shear rate $(\mathbf{B})$, and $Q(\mathbf{C})$ profiles in the resting cremaster muscle microcirculation of C57BL, BERK, and BERK $+\gamma$ mice. Microvascular blood flow in the BERK mice is characterized by a pronounced decline in arteriolar wall shear rates, and by a greater $Q$ in A2 and V2 vessels. Note the normalization of wall shear rates and $Q$ in BERK $+\gamma$ mice to control values. ${ }^{*} P<0.05$ vs. C57BL and BERK mice (Kruskal-Wallis test for ANOVA); ${ }^{\dagger} P<0.05$ vs. C57BL mice.
$V_{\mathrm{rbc}}\left(V_{\text {mean }}\right)$, showed marked decreases in BERK mice, i.e., $40-58 \%$ decreases in arterioles and an approximately $35 \%$ decrease in smalldiameter postcapillary venules (V4 and V3), as compared with C57BL controls $(P<0.05)$. There were no significant differences in arteriovenous wall shear rates among C57BL, BERK-trait, and $\beta$-thal mice (data not shown). To ascertain the effect of vasodilation on flow in BERK mice, $Q$ was calculated from $V_{\text {mean }}$ and vessel diameter. As shown in Figure 2C, arteriovenous $Q$ showed a parabolic pattern in each group of mice. In each group, the highest $Q$ values (in $\mathrm{nl} / \mathrm{s}$, mean $\pm \mathrm{SE}$ ) were obtained for A2 and V2 vessels. Notably, vasodilation was accompanied by $44-56 \%$ greater flow rates in A2 and V2 vessels of BERK mice than in those of C57BL controls $(P<0.05)$. There were no significant differences in $Q$ among C57BL, $\beta$-thal, and BERK-trait mice (data not shown).

\section{Hemodynamic parameters: the effect of $\mathrm{HbF}$}

BERK $+\gamma$ mice, which express $80 \% \beta^{\mathrm{S}}$-globin and $20 \% \gamma$-globin, were examined to determine the antisickling effect of $\mathrm{HbF}$ and its consequences for hemodynamic and microvascular flow parameters. In contrast to BERK mice ( $<1 \% \gamma$-globin), BERK $+\gamma$ mice $(n=9)$ showed a markedly increased MAP $(90.3 \pm 1.9$ vs. $65.2 \pm 2.4$ $\mathrm{mmHg} ; P<0.00001)$, accompanied by a significant decrease in microvascular diameters $(P<0.05)$; the resulting vessel diameters were not significantly different from those in control groups of mice (Table 2). Furthermore, both arteriovenous wall shear rates and volumetric flow showed significant reductions in BERK $+\gamma$

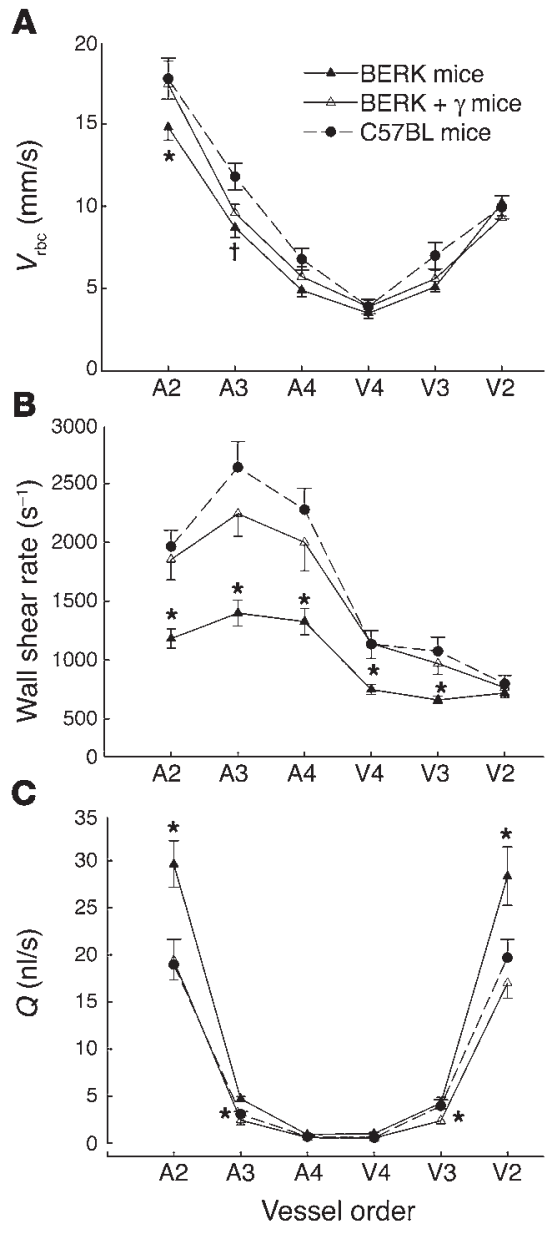




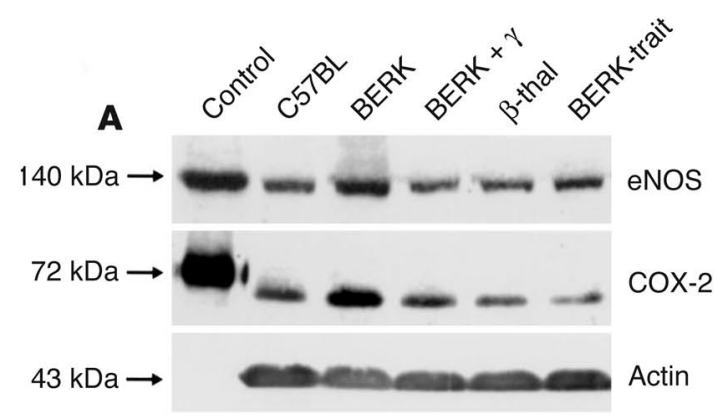

B
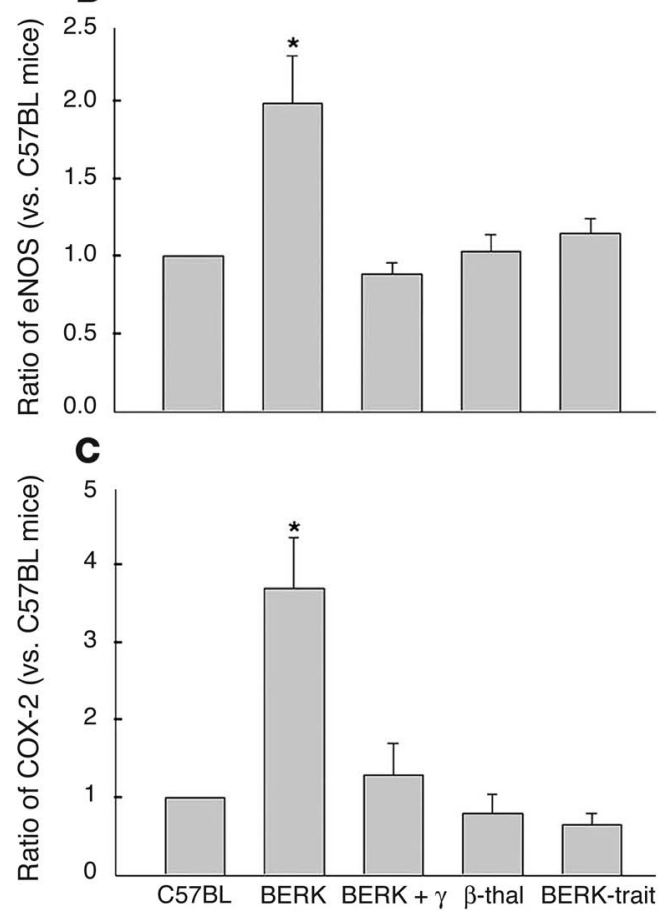

mice compared with BERK mice $(P<0.05$; Figure 2, B and C) and were not significantly different from those in control mice; this confirmed a trend toward normalization of microhemodynamic parameters in BERK $+\gamma$ mice.

\section{Vasoactive molecules: the effect of $\mathrm{HbF}$}

To determine whether the pronounced vasodilation and systemic hypotension in BERK mice are secondary to upregulation and/or induction of vasodilator species, we explored the status of NO synthase (NOS) and COX- 2 in BERK, BERK $+\gamma$, and control mice. While chronic hypoxia associated with low hematocrit and intravascular sickling may cause upregulation of NOS, COX-2 is induced during hypoxic and inflammatory conditions.

\section{Figure 4}

Immunoperoxidase staining for eNOS in the cremaster muscle microvasculature of C57BL, BERK, and BERK $+\gamma$ mice. (A) Negative control. Arrowheads indicate blood vessels. (B) The same vessels in an adjacent section from control C57BL cremaster muscle show positive reaction for eNOS in the vessel wall (arrowheads). (C) BERK mice show a strongly positive reaction in the vessel wall (arrowheads). (D) In contrast to BERK mice, BERK $+\gamma$ mice show a distinct decrease in the intensity of staining for eNOS in vessels (arrowheads).

\section{Figure 3}

Western blot analysis of cremaster muscle lysates for eNOS and COX-2 in BERK, BERK $+\gamma$, and control groups (C57BL, $\beta$-thal, and BERKtrait) of mice. (A) Note the higher expression of eNOS and COX-2 proteins in BERK mice. (B) Densitometric analysis of Western blot confirmed an average 2-fold increase in eNOS in BERK mice as compared with control C57BL mice, but no appreciable differences in the eNOS expression were observed between BERK $+\gamma$ and control mice. (C) Densitometric analysis of COX-2 expression showed an average 3.7-fold increase compared with control C57BL mice. No appreciable differences were noted between BERK $+\gamma$ mice and control groups. ${ }^{*} P<0.05$ (multiple comparisons by ANOVA).

Upregulation of eNOS protein expression. Western blot analysis using a $\mathrm{mAb}$ directed against eNOS showed that expression of eNOS $(140 \mathrm{kDa})$ was distinctly increased in BERK mice (Figure $3 \mathrm{~A})$. Densitometric analysis of Western blots confirmed an average 2-fold increase (range, 1.4- to 3.3-fold) in eNOS in BERK mice compared with controls ( $n=6$ each) (Figure $3 \mathrm{~B}$ ). A comparison of eNOS expression among various groups of mice confirmed higher expression in BERK mice $(P<0.05$, multiple comparisons by ANOVA), and no appreciable differences in eNOS expression were noted between BERK $+\gamma(n=3)$ and other control groups (C57BL, $\beta$-thal $[n=3]$, and BERK-trait $[n=3]$ ); this indicated an ameliorating effect of $\mathrm{HbF}$ (Figure $3 \mathrm{~B}$ ).

Lack of induction of $i N O S$. Using a mAb specific to iNOS, we did not find any evidence of iNOS expression using Western blots of the cremaster and kidney lysates in 3 C57BL control mice and 3 BERK mice.

COX-2 protein expression. Western blot analysis of cremaster muscle lysates for COX-2 was carried out using murine polyclonal antibodies against COX-2. As shown in Figure 3A, C57BL control mice showed a low level of COX-2 expression. A low level of COX-2 expression has been previously reported in control brain tissue and unperturbed endothelial cells $(28,29)$. In contrast, BERK mice showed a significantly increased expression of COX-2. Densitometric analysis of Western blots showed an average 3.7fold increase (range, 1.6- to 6.2-fold) in COX-2 in BERK mice compared with controls ( $n=8$ each) (Figure 3C). A comparison of COX-2 expression among various groups of mice confirmed a higher expression in BERK mice $(P<0.05)$, while no appreciable differences were observed between BERK $+\gamma$ mice $(n=3)$ and control groups (C57BL, $\beta$-thal $[n=3]$, and BERK-trait $[n=3]$ ) (Figure $3 C)$; this further suggested an anti-inflammatory effect of antisickling $\mathrm{HbF}$ in BERK $+\gamma$ mice.

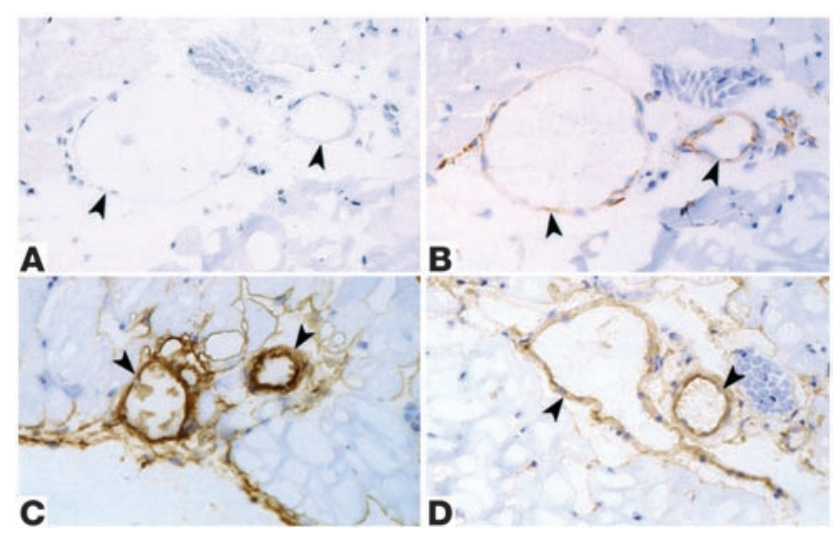




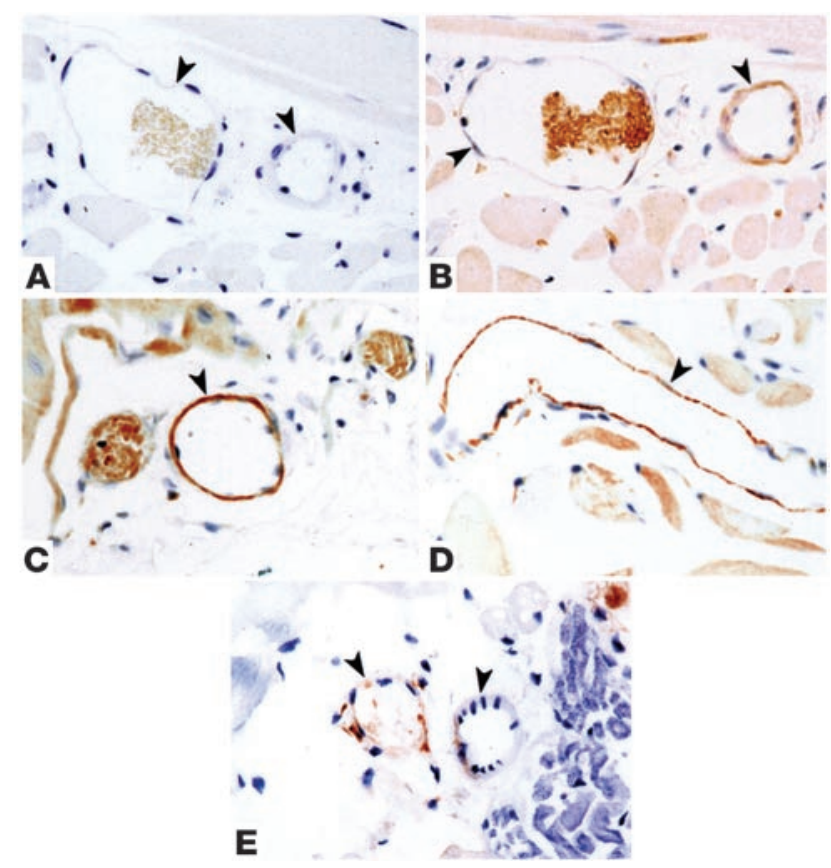

Immunohistochemistry. Microvascular expression of eNOS and COX-2 was determined in the cremaster muscle preparation of C57BL, BERK, and BERK $+\gamma$ mice. As shown in Figure 4B, vascular endothelium of C57BL mice was distinctly positive for eNOS. In contrast, the staining for eNOS in the cremaster vessels of BERK mice was greatly enhanced (Figure 4C) compared with that in the control tissue, while BERK $+\gamma$ mice showed a marked decrease in the staining for eNOS in blood vessels compared with BERK mice (Figure 4D). Immunohistochemistry for COX-2 revealed negative to weakly positive expression of the enzyme in the cremaster blood vessels of control C57BL mice (Figure 5B). In contrast, BERK mice showed a marked enhancement of COX-2 expression in the endothelium of most blood vessels (Figure 5, C and D). On the other hand, COX-2 expression in BERK $+\gamma$ mice was distinctly low compared with that in BERK mice (Figure 5E) and similar to that observed in control C57BL mice. The specificity of immunohistochemical reactions was confirmed by negative controls for eNOS and COX-2 (Figures 4A and 5A).

\section{Vascular reactivity: the effect of $\mathrm{HbF}$}

Response to ACh, an endothelium-dependent vasodilator. As shown in Figure $6 \mathrm{~A}$, topical $\mathrm{ACh}\left(10^{-6} \mathrm{M}\right)$ caused $87.7 \%$ and $73.6 \%$ increases, respectively, in arteriolar (A3) diameters (mean $\pm \mathrm{SE}$ ) in C57BL controls $(22.6 \pm 2.9$ to $41.5 \pm 4.7 \mu \mathrm{m}, P<0.0003, n=7)$ and BERK-trait mice $(21.6 \pm 2.5$ to $36.5 \pm 3.0 \mu \mathrm{m}, P<0.0001, n=10)$. In contrast, BERK mice showed an attenuated response as evidenced by an only

\section{Figure 6}

Arteriolar diameter responses (percent increase) to topical application of ACh $\left(10^{-6} \mathrm{M}\right)$ and SNP $\left(10^{-6} \mathrm{M}\right)$ in C57BL, BERK-trait, BERK, and BERK $+\gamma$ mice. Note the attenuated response of arterioles in BERK mice to ACh (A) and SNP (B). ACh and SNP caused significant increases in arteriolar diameters of BERK $+\gamma$ mice as compared with those in BERK mice ( 33\% and $\sim 50 \%$ increases, respectively). ${ }^{\star} P<0.005-0.000001$ vs. C57BL and BERK-trait mice. ${ }^{\dagger} P<0.00-0.002$ vs. BERK mice.

\section{Figure 5}

Immunoperoxidase staining for COX-2 in the cremaster muscle microvasculature of C57BL, BERK, and BERK $+\gamma$ mice. (A) Negative control. Arrowheads indicate blood vessels. (B) The same vessels in an adjacent section from control C57BL cremaster muscle show negative to weakly positive reaction (arrowheads). (C and D) Strongly positive reaction for COX-2 in vascular endothelium of blood vessels in BERK mice (arrowheads). (E) BERK $+\gamma$ mice show negative or weakly positive reaction for COX-2 in vessel walls (arrowheads).

$7 \%$ increase ( $P<0.00001$ vs. C57BL and BERK-trait mice) in arteriolar diameters from $27.8 \pm 2.3$ to $29.8 \pm 2.8 \mu \mathrm{m}(n=11)$. In BERK $+\gamma$ mice, ACh resulted in an approximately $33 \%$ increase in the diameter $(25.8 \pm 2.3$ to $33.9 \pm 2.3 \mu \mathrm{m}, P<0.002, n=7)$, and this response was significantly greater than that in BERK mice $(P<0.001)$, although the percentage increase in the diameter was significantly less pronounced than in C57BL and BERK-trait mice $(P<0.01)$.

Response to $S N P$, an endothelium-independent vasodilator. Figure $6 \mathrm{~B}$ shows the effect of SNP, an NO donor, on the arteriolar (A3) diameter. Topical SNP $\left(10^{-6} \mathrm{M}\right)$ caused $78 \%$ and $64 \%$ increases, respectively, in arteriolar diameters (mean $\pm \mathrm{SE}$ ) in C57BL controls $(22.3 \pm 2.9$ to $40.5 \pm 4.5 \mu \mathrm{m}, P<0.00001, n=7)$ and BERK-trait mice $(19.9 \pm 2.1$ to $32.4 \pm 2.9 \mu \mathrm{m}, P<0.001, n=6)$. On the other hand, BERK mice showed an attenuated response as evidenced by an only $13 \%$ increase in the diameter $(27.4 \pm 2.5$ to $30.7 \pm 2.5 \mu \mathrm{m}, n=11, P<0.001$ vs. C57BL and BERK-trait mice). In BERK $+\gamma$ mice, SNP caused an almost $50 \%$ increase in the diameter $(23.9 \pm 2.8$ to $33.9 \pm 2.1 \mu \mathrm{m}, P<0.001)$. The percentage increase in the diameter in BERK $+\gamma$ mice was significantly greater than that in BERK mice $(P<0.002)$, but significantly less than that in C57BL mice $(P<0.01)$.

Response to nitro-L-arginine methylester. Next, we evaluated NOS activity by evaluating the response of MAP to intravenous infusion of nitro-L-arginine methylester (L-NAME) $(20 \mathrm{mg} / \mathrm{kg}$ for $10 \mathrm{~min}$ utes), a potent nonselective inhibitor of NOS. As is evident from Figure 7A, L-NAME caused significant blood pressure increases $(\sim 25-28 \%)$ at 30 minutes in male C57BL $(n=5)$ and BERK $+\gamma(n=3)$ mice compared with the baseline (pre-L-NAME) values $(P<0.001$ and 0.044 , respectively). In contrast, male BERK mice $(n=7)$

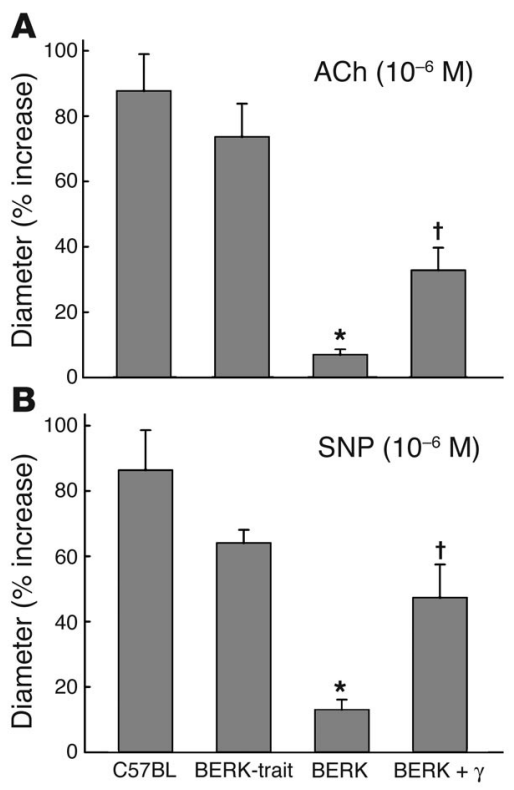



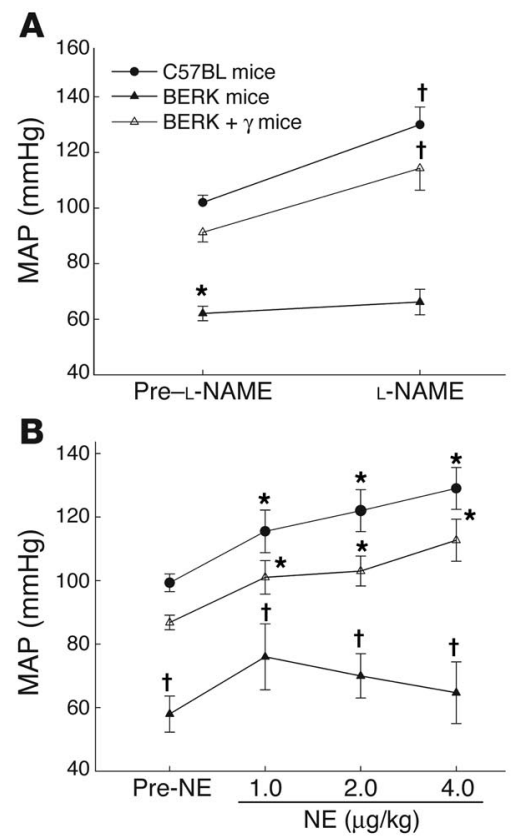

Figure 7

(A) The effect of L-NAME $(20 \mathrm{mg} / \mathrm{kg})$ on MAP in C57BL, BERK, BERKtrait, and BERK $+\gamma$ mice. L-NAME caused significant increases in MAP in C57BL and BERK-trait mice as compared with pre-L-NAME values. In contrast, BERK mice showed an attenuated response. (B) The effect of norepinephrine (NE; 1, 2, and $4 \mu \mathrm{g}$ ) on MAP in C57BL, BERK, and BERK $+\gamma$ mice. NE caused dose-dependent increases in MAP in C57BL and BERK $+\gamma$ mice compared with pre-NE values, but an attenuated response in BERK mice. ${ }^{*} P<0.05$ vs. C57BL and BERK $+\gamma$ mice (multiple comparisons by ANOVA). ${ }^{\dagger} P<0.05$ vs. pre-NE values ( $t$ test).

showed an attenuated response as indicated by a less than $7 \%$ increase in MAP after L-NAME infusion $(P=0.29)$.

In separate experiments, we evaluated the effect of L-NAME infusion on MAP in female C57BL $(n=5)$ and BERK $(n=6)$ mice to ascertain whether the MAP response showed a sexual dimorphism. In female C57BL mice, L-NAME caused an approximately $23 \%$ increase in MAP $(98.6 \pm 1.8$ to $120.8 \pm 2.3 \mathrm{mmHg}, P<0.003)$, which showed no significant difference from the values depicted for the males in Figure 7A. On the other hand, in female BERK mice, L-NAME caused a greater than $13 \%$ increase $(69.7 \pm 6.1$ to $79.0 \pm 5.8 \mathrm{mmHg}, P>0.004)$, which showed a still muted but greater response to L-NAME than in male BERK mice (Figure 7A).

The effect of norepinephrine. As depicted in Figure $7 \mathrm{~B}$, intravenous infusion of norepinephrine (NE) $(1-4 \mu \mathrm{g} / \mathrm{kg}, n=4 \mathrm{each})$ produced a significant progressive increase in MAP in both control C57BL and BERK $+\gamma$ mice; in each group NE at $4 \mu \mathrm{g} / \mathrm{kg}$ resulted in a $30 \%$ increase in MAP $(P<0.05)$. On the other hand, NE caused an attenuated response in BERK mice, and there was no progressive rise in MAP with the increasing dose of NE. Moreover, at any given dose of NE, MAP remained significantly lower in BERK mice $(n=4)$ than in C57BL and BERK $+\gamma$ mice $(P<0.05$, multiple comparisons).

In the above experiments wherein we used cremaster preparation, we cannot discount some inflammatory effect of tissue exteriorization, which has been observed by others $(27,30)$. Nevertheless, our results demonstrate distinct differences in hemodynamic profiles and vascular reactivity among control, BERK, and BERK $+\gamma$ mice subjected to the same exteriorization procedure. We also observed distinct differences in eNOS and COX-2 expression in rapidly excised cremaster tissue among these mice.

\section{Nitrotyrosine: the effect of $\mathrm{HbF}$}

Since BERK mice exhibited attenuated responses to both NOmediated vasodilators (ACh and SNP) and a NOS inhibitor (L-NAME), we investigated whether these effects were related to increased oxidative stress. Western blot analysis of cremaster muscle extracts (Figure 8) showed 2 prominent bands of nitrated proteins, corresponding approximately to 66 and $26 \mathrm{kDa}$. In 2 BERK mice, tyrosine nitration of the $66-\mathrm{kDa}$ protein was increased 6.2- and 4.8-fold compared with that in the C57BL control, while tyrosine nitration of the $26-\mathrm{kDa}$ protein was increased 2 - and $1.7-$ fold. In the BERK $+\gamma$ mouse, tyrosine nitration of the 66 - and $26-\mathrm{kDa}$ proteins showed smaller increases (i.e., 2.3- and 1.3-fold, respectively) compared with that in the $\mathrm{C} 57 \mathrm{BL}$ control, indicating a protective effect of $\mathrm{HbF}$ against oxidative stress. The BERK-trait mouse showed smaller increases of 1.1- and 1.4-fold, respectively, for nitration of the 66 - and $26-\mathrm{kDa}$ proteins, while the respective ratios for the $\beta$-thal mouse were 0.1 and 1.0.

\section{Discussion}

We show that in the BERK mouse model of sickle cell disease, intravascular sickling, increased oxidative stress, and hemolytic anemia are accompanied by vasodilation, compensatory increases in eNOS and COX-2, and attenuated vascular responses to NOmediated vasoactive stimuli and NE. The hypotension and vasodilation (required for adequate oxygen delivery in the face of chronic anemia) in this mouse model are mediated by non-NO vasodilators (i.e., prostacyclin) as evidenced by induction of COX-2. The resistance to NO-mediated vasodilators in BERK mice is associated with an increased oxidative stress and hemolytic rate, and an improved response to these stimuli in BERK $+\gamma$ mice (expressing $20 \% \mathrm{HbF}$ ) is associated with a decreased oxidative stress and hemolytic rate. Also, in the presence of antisickling $\mathrm{HbF}, \mathrm{BERK}+\gamma$ mice show normalization of vessel diameters, and $\mathrm{NOS}$ and COX-2 expression.

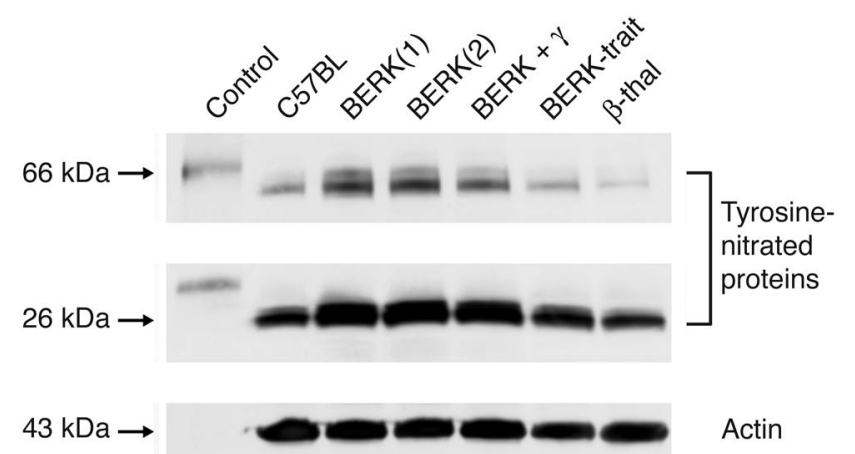

\section{Figure 8}

Western blot analysis of cremaster muscle lysates for the expression of nitrotyrosine. Two prominent bands of nitrated proteins were detected by the antibody to nitrotyrosine, corresponding to approximately 66 and $26 \mathrm{kDa}$. BERK mice showed increased tyrosine nitration of both 66- and 26-kDa proteins (average increase, 5-fold and about 2-fold, respectively), while the BERK $+\gamma$ mouse showed smaller increases as compared with C57BL controls. The nitrotyrosine levels in BERK-trait and $\beta$-thal mice showed no increase as compared with C57BL controls. Equal loading of the samples was ascertained using anti-actin antibody. 
Oxidative stress in BERK mice. The increased oxidative stress in this mouse model is likely the result of extensive intravascular sickling, the presence of $\beta$-thalassemia features, blood cell-endothelium interactions, and recurring transient occlusive events. Sickling and transient vaso-occlusive events can result in endothelial activation, as shown in a transgenic mouse model in which hypoxia/ reoxygenation resulted in an exaggerated inflammatory response (i.e., endothelial oxidant generation and leukocyte recruitment) compared with that in normal mice $(2,3)$. These results imply that intravascular sickling and associated hypoxia/reoxygenation events in sickle cell disease will result in chronic oxidative stress. Consistent with these observations, Aslan and coworkers (10) have reported that both sickle cell disease patients and BERK mice show elevated plasma xanthine oxidase activity accompanied by increased vascular superoxide $\left(\mathrm{O}_{2}{ }^{\bullet-}\right)$ production.

The present studies show that the oxidative stress in BERK mice is associated with increased production of nitrotyrosine. Tyrosine nitration can occur when $\mathrm{O}_{2}{ }^{-}$reacts with $\mathrm{NO}$ to form peroxynitrite $\left(\mathrm{ONOO}^{-}\right)$, which can nitrate tyrosine residues (31). A major mechanism contributing to this process is hemin-mediated nitrated-tyrosine formation in the presence of nitrite and hydrogen peroxide $\left(\mathrm{H}_{2} \mathrm{O}_{2}\right)$ (32). Furthermore, the increased oxidative stress and chronic hypoxia (intravascular sickling and low hematocrit) in the BERK model are associated with the induction of COX-2. Unlike COX-1, which is constitutively expressed, COX-2 is an inducible enzyme with low or undetectable levels under normal conditions. COX-2 is induced under conditions of chronic hypoxia and inflammation, resulting in a greater production of $\mathrm{PGE}_{2}$, a vasodilator prostanoid $(33,34)$.

In the BERK mouse, COX-2 expression is confirmed by both Western blotting and immunohistochemistry, with the latter confirming its localization in microvascular endothelium. We propose that the induction of COX-2 and associated vasodilation is a compensatory response to accomplish adequate oxygen delivery under conditions of anemia. Also, another vasodilator enzyme, heme oxygenase-1, with antioxidant properties is induced in both transgenic sickle mice and human sickle cell disease patients $(35,36)$. During ischemic/reperfusion events, endothelial generation of $\mathrm{H}_{2} \mathrm{O}_{2}$, a vasodilator and hyperpolarizing factor $(37,38)$, may also contribute to vasodilation. We also find increased expression of eNOS in the BERK model and confirm its upregulation in vascular endothelium. However, the bioavailability of $\mathrm{NO}$ may be impaired by increased oxidant generation, as well as by cell-free hemoglobin (15). On the other hand, the cremaster tissue, while positive for eNOS, was negative for iNOS, which is in agreement with previous reports in transgenic sickle mice $(18,19)$.

Microvascular and hemodynamic abnormalities in BERK mice. The results show that microcirculatory blood flow in BERK mice is markedly affected by intravascular sickling, hemolysis, and attendant anemia. This is evidenced by pronounced $40 \%$ dilation of the resistance vessels (i.e., arterioles), average reduction of $40 \mathrm{mmHg}$ in MAP, and an almost $50 \%$ increase in $Q$ as compared with those in C57BL mice. No significant differences in the vessel diameters and flow were noted among C57BL, BERK-trait, and $\beta$-thal mice. Notably, $\beta$-thal mice have anemia but no intravascular sickling or significant hemolysis. In contrast, in BERK mice, anemia combined with sickling and hemolysis results in vasodilation to facilitate optimal oxygen delivery. In addition, in BERK mice, sickling, increased blood cell-endothelium interactions, and vasodilation contribute to a marked decrease in wall shear rates in both arte- rioles (40-58\% decrease) and venules (V4 and V3, approximately a $35 \%$ decrease) compared with those in C57BL controls.

Systemic hypotension coupled with arteriolar dilation indicates decreased vascular resistance in BERK mice. Although no comparable microcirculatory measurements exist for sickle cell disease patients, several studies have demonstrated that low blood pressure in these patients is associated with almost $50 \%$ reduction in the peripheral resistance $(12,39)$. The reduced peripheral resistance in sickle cell disease patients is also associated with a significant increase in $Q$ in large arteries $(16,20)$. Such hemodynamic alterations in sickle cell disease patients may be due to altered microvascular control (vasodilation) as observed in BERK mice and may reflect contribution of non-NO-mediated vasodilators, namely, prostaglandins.

Vascular reactivity. Further insights into microvascular control mechanisms in BERK mice come from the characteristics of vessel responses to the NO-mediated vasodilators ACh and SNP. In contrast to $65-80 \%$ arteriolar dilation induced by ACh (an endotheliumdependent vasodilator) and SNP (an NO donor) in control mice (C57BL and BERK-trait mice), BERK mice showed minimal effects of these NO-mediated vasodilators on arteriolar diameters ( $7 \%$ and $13 \%$, respectively). Furthermore, L-NAME, an inhibitor of NOS activity, caused a significant increase in blood pressure in both male and female C57BL mice. Among BERK mice, compared with the attenuated response in males, the females showed a statistically significant increase in blood pressure that, however, did not reach the level of C57BL controls. Sex differences in L-NAME responses have been reported in humans with sickle cell disease (20) and may indicate sexual dimorphism in NO bioactivity.

In the BERK model, almost complete resistance to exogenous NO (i.e., SNP) demonstrates inactivation and/or destruction of NO. The BERK model differs markedly from ischemic coronary artery disease, which is characterized by blunted responses to LNMMA but normal responses to SNP (11). In sickle cell disease, increased oxidative stress (10) and systemic effects of chronic hemolysis (15) both may contribute to NO inactivation. NO reacts at least 1,000 times more rapidly with cell-free ferrous hemoglobin than with red cells. Also, an increase in endothelium-bound xanthine oxidase, which has been reported in BERK mice (10), could catalyze the increased generation of $\mathrm{O}_{2}{ }^{-}{ }^{-}$and $\mathrm{H}_{2} \mathrm{O}_{2}$, thereby interfering with vessel responses to $\mathrm{NO}$-mediated vasodilators. While increased $\mathrm{O}_{2}{ }^{-}{ }^{-}$could potentially react with $\mathrm{NO}$, as suggested by Aslan et al. (10), $\mathrm{H}_{2} \mathrm{O}_{2}$ is required in hemin-mediated nitratedtyrosine formation (32). Thus, in BERK mice, NO bioavailability is likely impaired by increased oxidative stress and hemolytic rate.

Next, increased oxidative stress and formation of nitrated proteins (via $\mathrm{ONOO}^{-}$and/or hemin-mediated pathways) may itself cause chronic vascular injury and impaired vascular reactivity. Previous studies have shown that nitrotyrosine (3-nitro-L-tyrosine) infusion in rats leads to attenuated hemodynamic responses to catecholamines (epinephrine and NE) and angiotensin II (40, 41), which is comparable to the attenuated blood pressure response to NE observed in the present studies. Previously reported attenuated hemodynamic response to angiotensin II in sickle cell disease patients (42) may also involve a similar mechanism.

The effect of $\mathrm{HbF}$. BERK $+\gamma$ mice expressing $80 \% \mathrm{HbS}$ and $20 \% \gamma$-globin levels show improvement in both $\beta$-globin: $\alpha$-globin chain ratio and $\mathrm{MCH}$, which indicates a significant alleviation of thalassemic features of BERK mice. We also find a distinct increase in hematocrit levels accompanied by reduced hemolytic rate as compared with 
BERK mice. However, higher-than-normal levels of plasma hemoglobin in BERK $+\gamma$ mice indicate persistent hemolysis, a condition comparable to that observed in sickle cell disease patients on hydroxyurea therapy (36). Nevertheless, the inhibitory effect of $\mathrm{HbF}$ on red cell sickling in BERK $+\gamma$ mice and the likely decrease in sickling-induced transient vaso-occlusive events result in normalization of several microvascular and hemodynamic parameters. First, in these mice, microvascular diameters, wall shear rates, and $Q$ are not significantly different from those in control C57BL mice. Second, in BERK $+\gamma$ mice, MAP shows a significant increase as compared with that in BERK mice, further indicating normalization of vascular tone. Third, the normalization of vascular tone (i.e., arteriolar diameter) is associated with a marked decrease in COX-2 and eNOS expression in microvascular endothelium, almost to the control levels. Finally, in contrast to BERK mice, BERK $+\gamma$ mice exhibit an improved response to NO-mediated vasoactive stimuli (ACh, SNP, and L-NAME), as well as to a vasoconstrictor (NE), indicating a trend toward normalization of vascular reactivity. It is, however, worthwhile to note that, while some pathology is completely corrected by the introduction of $\mathrm{HbF}$ (e.g., vessel diameters, COX-2 and eNOS expression), the response to vasoactive stimuli such as Ach and SNP is only partially corrected. This suggests that, even when the vessel diameter is normal, the signaling pathways for the maintenance of vascular tone are still disrupted in BERK $+\gamma$ mice, perhaps because of higher-than-normal oxidant generation and hemolytic rates in these mice.

In conclusion, the present studies demonstrate that $\mathrm{HbS}$ polymerization, intravascular sickling, and attendant vaso-occlusive events in the BERK mouse are associated with significant microvascular and hemodynamic adaptations. The arteriolar dilation coupled with increased blood flow is a compensatory response to provide adequate oxygen delivery in the face of chronic anemia. The vasodilation is associated with induction of COX-2 and increased expression of eNOS. However, resistance to NO-mediated vasodilators and L-NAME suggests inactivation of NO secondary to increased oxidative stress and hemolytic rate. The attenuated response to NE indicates that oxidative damage and tyrosine nitration may affect vascular smooth muscle function. In contrast, increasing $\mathrm{HbF}$ levels to $20 \%$ results not only in normalization of microvascular parameters in BERK $+\gamma$ mice, but also in decreased expression of eNOS and COX-2 almost to the control levels. Importantly, in BERK $+\gamma$ mice, the decrease in oxidative stress and hemolytic rate is accompanied by improved responses to NO-mediated vasoactive stimuli and NE. These results demonstrate a strong relationship between sickling and microvascular function in sickle cell disease.

\section{Methods}

\section{Transgenic mice}

BERK mice expressing cointegrated 6.4-kb miniLCR, a 1.5-kb PstI fragment of human $\alpha 1$ gene, and a 39-kb KpnI fragment containing human $\mathrm{G}_{\gamma} \mathrm{A}_{\gamma} \delta$ and $\beta^{\mathrm{S}}$-globin genes were generated as previously described (43). These mice are homozygous for the mouse $\alpha$-knockout (44) and homozygous for the mouse $\beta$-knockout (45) and express exclusively human hemoglobin via the hemizygous copy of the BERK transgene (43). We generated BERK $+\gamma$ mice by breeding in the $\gamma$-transgene generated by Gilman (46), as described by Fabry et al. (24). These mice are also homozygous for both the $\alpha$ - and the $\beta$-knockouts and express exclusively human hemoglobin via a hemizygous copy of the BERK transgene and a hemizygous copy of the $\gamma$-transgene. The BERK-trait mouse was used as one of the controls. This mouse is homozygous for the $\alpha$-knockout, hemizygous for the $\beta$-knockout, and hemizygous for the BERK transgene. One copy of the BERK transgene results in expression of $15 \%$

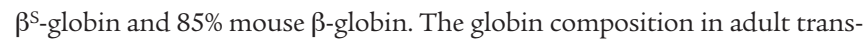
genic-knockout mice was determined by HPLC as previously described (24). The controls included C57BL/6J (C57BL) mice and C57BL $\beta$-thal ( $\beta$-thal) mice.

The control C57BL and $\beta$-thal mice were maintained on a standard diet and water ad libitum. Sickle mice were maintained on "sickle chow" developed by Paszty et al. (43) (diet no. 5740C; Purina Mills Inc.), without added arginine, and had access to Nestlets (Ancare) nesting material. All experimental protocols were approved by the Animal Institute Committee of the Albert Einstein College of Medicine.

\section{Hematological parameters}

Blood samples obtained from the tail were analyzed for the $\mathrm{MCH}$ using the Sysmex SE-9000 system (TOA Medical Electronics Co.). Percentage reticulocytes was determined in smears stained by New methylene blue (Sigma-Aldrich). Hematocrit in plasma was directly measured using a microcapillary centrifuge (model MB; International Equipment Company). For plasma-free hemoglobin, blood samples were drawn from the mouse left ventricle, and determinations were made using a benzidinebased assay kit (Catachem Inc.).

\section{Microcirculatory studies}

C57BL control $(n=51)$, BERK $(n=51), \operatorname{BERK}+\gamma(n=31), \beta$-thal $(n=17)$, and BERK-trait $(n=19)$ mice weighing approximately $25-30 \mathrm{~g}(4-6$ months old) were used. Mice were anesthetized intraperitoneally with $10 \%$ urethane and $2 \% \alpha$-chloralose in saline $(5 \mathrm{ml} / \mathrm{kg})$. The animals were tracheostomized. The right jugular vein was cannulated for infusion of vasoactive substances. To monitor arterial pressure, the left carotid artery was cannulated using PE10 polyethylene tubing. In vivo microcirculatory observations were made in the open cremaster muscle preparation, prepared according to the method of Baez (47). The suffusion and maintenance of the mouse cremaster preparation were done as previously described (17). Briefly, the open cremaster preparation was suffused with bicarbonate Ringer's solution (in mmol: $\mathrm{NaCl} 135.0, \mathrm{KCl} 5.0, \mathrm{NaHCO}_{3} 27.0, \mathrm{MgCl}_{2} 0.64$, and glucose 11.6; $\mathrm{pH}$ adjusted to $7.35-7.4$ by bubbling with $94.6 \% \mathrm{~N}_{2}$ and $5.6 \% \mathrm{CO}_{2}$ ). The osmolarity of Ringer's solution was adjusted to $330 \mathrm{mOsm}$, which is similar to that of the mouse plasma, and the temperature of suffusion solution was maintained at $34.5-35^{\circ} \mathrm{C}$. Microscopic observations were carried out using a Nikon microscope (model E400; Morrell Instrument Co.) equipped with a CCD television camera (model CCD-300T-RC; Dage-MTI Inc.) and a Sony U-matic video recorder (model VO5800; Sony Corp.).

Diameter and $V_{\mathrm{rbc}}$ measurements were made in $\mathrm{A} 2, \mathrm{~A} 3$, and $\mathrm{A} 4$ arterioles and V2, V3, and V4 venules. Vessel luminal diameter $(D)$ was measured online using an image shearing device (model 908; Vista Electronic Co.). $V_{\mathrm{rbc}}$ was measured along the vessel centerline using a "dual-slit" photodiode and a velocity cross-correlator (model $102 \mathrm{BF}$; Vista Electronic Co.) (48, 49). The centerline $V_{\mathrm{rbc}}$ was converted to the $V_{\text {mean }}$ across the vessel diameter using a conversion factor of $1.6\left(V_{\mathrm{rbc}} / V_{\text {mean }}=1.6\right)$, originally described by Baker and Wayland (50) and later validated by Seki and Lipowsky (51). $Q$ was determined from $V_{\text {mean }}$ and the vessel cross-sectional area $\left(\pi D^{2} / 4\right)$ as described elsewhere (50). Shear rates along the wall of a microvessel of a given luminal diameter were calculated using the relationship $8 \times V_{\text {mean }} / D(17)$.

In a series of experiments, arteriolar responses to topical application of ACh $\left(10^{-6} \mathrm{M}\right.$; Sigma-Aldrich) and SNP $\left(10^{-6} \mathrm{M}\right)$, both NO-mediated vasodilators, were compared in control, BERK, and BERK $+\gamma$ sickle mice. After base-line measurements, suffusion with bicarbonate Ringer's solution was interrupted, and ACh or SNP prepared in the same medium was topically applied. Vessel diameter and $V_{\mathrm{rbc}}$ were measured after 3 minutes of the topical application. As reported previously, both ACh and SNP resulted in maximal vasodilatory effects in control mice when the concentration 
of each was increased from $10^{-8}$ to $10^{-6} \mathrm{M}$, and increasing the concentration to $10^{-5} \mathrm{M}$ caused no appreciable further increase in the diameter (18). Hence, the concentration of $10^{-6} \mathrm{M}$ was selected in each case. Ten minutes were allowed to lapse before the next topical application. In general, diameters returned to baseline levels within 10 minutes.

In separate experiments, blood pressure response to the infusion of L-NAME (Sigma-Aldrich) and NE was evaluated in C57BL, BERK, and BERK $+\gamma$ mice. L-NAME $(20 \mathrm{mg} / \mathrm{kg})$ was infused intravenously over 10 minutes, and MAP was measured after 30 minutes. NE (Abbott Laboratories) was infused intravenously via the jugular vein at increasing concentrations of 1,2 , and $4 \mu \mathrm{g} / \mathrm{kg}$, as described elsewhere (40).

\section{Western blots}

The cremaster tissue was rapidly excised, rinsed in saline, and homogenized in boiling buffer (1\% SDS in $10 \mathrm{mM}$ Tris-HCl, $\mathrm{pH}$ 7.4). The homogenate was boiled for 5 minutes, cooled in ice, and centrifuged at 9,000 $\mathrm{g}$ for 5 minutes to remove insoluble material. After 2 passages of the supernatant through a 26-gauge needle, $50 \mu \mathrm{l}$ of the supernatant was mixed with $0.45 \mathrm{ml}$ of deionized $\mathrm{H}_{2} \mathrm{O}$ and $2 \mathrm{ml}$ of biuret reagent, and protein concentration was determined on a spectrophometer at $320 \mu \mathrm{m}$. For Western blotting of eNOS and iNOS (mol wt, 140 and $130 \mathrm{kDa}$, respectively), SDS-PAGE was performed using 7.5\% acrylamide gels for separation. Molecular weight standards and a positive control (human endothelial lysate for eNOS, or mouse macrophage lysate for iNOS) and a negative control (lacking specific antibody) were also run. Monoclonal antibodies directed against human eNOS and mouse macrophage iNOS (Transduction Laboratories) were used as previously described (18). Western blotting of COX-2 (mol wt, $70 \mathrm{kDa}$ ) was done using a $10 \%$ acrylamide gel. Molecular weight standards and a positive control (Cos-1 cell lysate) were run as described above. After the transfer, the nitrocellulose membranes were treated with the blocking buffer and incubated with rabbit anti-mouse COX-2 polyclonal antibody (dilution, 1:1,000; Cayman Chemical Co.) for 1 hour at room temperature, followed by incubation with anti-rabbit IgG-HRP secondary antibody $(1: 10,000)$ for 1 hour at room temperature. Western blotting of nitrotyrosine-containing proteins was done using a 4-20\% linear-gradient gel (Bio-Rad Laboratories Inc.). Tyrosine-nitrated proteins with a range of molecular weights served as positive control (Upstate Biotechnology Inc.). The membranes were incubated overnight at $4{ }^{\circ} \mathrm{C}$ with a monoclonal anti-nitrotyrosine antibody (clone 1A5; Upstate Biotechnology Inc.) diluted 1:800 in the blocking buffer, followed by goat anti-mouse IgG-HRP $(1: 2,000)$ for 1 hour. To ascertain equal loading of samples, the membranes were stripped off in stripping buffer (Chemicon International Inc.) for 15 minutes, blocked for 30 minutes in the blocking buffer, and reincubated for 1 hour with goat anti-actin antibody (Santa Cruz Biotechnology Inc.) followed by incubation with anti-goat IgG-HRP secondary antibody $(1: 2,000)$ for 1 hour. In the above Western blotting procedures, the specific proteins were detected by ECL (DuPont). The protein bands on the developed film were scanned and quantified by computerized laser densitometry and ImageQuant software (Molecular Dynamics).

\section{Immunobistochemistry}

eNOS. The cremaster tissue was obtained from 3 groups of mice: control C57BL, BERK, and BERK $+\gamma$. Frozen cremaster tissue sections $(6 \mu \mathrm{m}$ thick) were fixed in acetone, dried for 20 minutes, washed with PBS, and blocked with 2\% BSA in PBS containing 5\% rabbit serum. Sections were incubated overnight at $4{ }^{\circ} \mathrm{C}$ with primary monoclonal anti-human eNOS (1:1,000; Transductions Laboratories). Omission of primary antibody was used as control. After 3 washes with PBS, the sections were then incubated with biotinylated rabbit anti-mouse antibody $(1: 1,000$; Chemicon International Inc.). Antibody-binding sites were visualized by incubation in avidin-biotin peroxidase complex solution (ABC complex, VECTASTAIN; Vector Laboratories Inc.) and 3,3'-diaminobenzidine (DAB; DAKO Corp.). Counterstaining was done with hematoxylin (Harris Hematoxylin; Poly Scientific R\&D Corp.). Survey and photomicroscopy were done using a Zeiss Axiophot microscope (Carl Zeiss Inc.) at a magnification of $\times 400$.

COX-2. Cremaster muscle tissue was obtained from the same 3 groups of mice as described above. The tissue was fixed in $10 \%$ neutral-buffered formalin immediately after exteriorization. Paraffin sections (5 $\mu \mathrm{m}$ thick) were deparaffinized in xylene, rehydrated through graded ethanols to water, and equilibrated in $1 \times$ PBS. Sections were pretreated for 20 minutes by steaming in $0.01 \mathrm{M} \mathrm{Na}$-citrate buffer ( $\mathrm{pH}$ 6.0; Vector Laboratories Inc.). Endogenous peroxidase was quenched with $0.3 \%$ $\mathrm{H}_{2} \mathrm{O}_{2}$ for 30 minutes, and 5\% BSA was used to block nonspecific binding. Sections were incubated overnight at $4{ }^{\circ} \mathrm{C}$ with polyclonal rabbit anti-mouse COX-2 antiserum (1:50; Cayman Chemical Co.). Omission of primary antibody was used as negative control. Sections were then incubated with biotinylated goat anti-rabbit IgG (1:200; Vector Laboratories Inc.) for 1 hour at room temperature. Visualization was by DAB as described above.

\section{Statistical analysis}

Statistical analysis was performed using Student's $t$ test or 1-way ANOVA with Newman-Keuls multiple comparisons. Where tests for normality failed, or Bartlett's test for homogeneity of variance showed significant difference in the standard deviations, nonparametric tests such as the KruskalWallis test for ANOVA or the Wilcoxon 2-sample test were used. Values are expressed as the mean $\pm \mathrm{SE}$. $P$ values less than 0.05 were considered significant. The statistical analysis was performed using STATGRAPHICS*Plus 3.0 for Windows (Manugistics Inc.).

\section{Acknowledgments}

The authors express thanks to S. Suzuka for invaluable help with genotyping of the knockout mice, and M. Cammer (Albert Einstein College of Medicine, Bronx, New York, USA) for assistance with photomicrography. This work was supported by NIH grants RO1 HL070047, HL55552, U54 HL38655, and P60 HL55435, and by a Grant-in-Aid from the American Heart Association (Heritage Affiliate).

Received for publication March 17, 2004, and accepted in revised form August 3, 2004.

Address correspondence to: Dhananjay K. Kaul, Department of Medicine, Room U-917, Albert Einstein College of Medicine, 1300 Morris Park Avenue, Bronx, New York 10461, USA. Phone: (718) 430-3702; Fax: (718) 430-8969; E-mail: kaul@aecom.yu.edu.

\footnotetext{
1. Kaul, D.K., Fabry, M.E., and Nagel, R.L. 1996. The pathophysiology of vascular obstruction in the sickle syndromes. Blood Rev. 10:29-44.

2. Osarogiagbon, U.R., et al. 2000. Reperfusion injury pathophysiology in sickle transgenic mice. Blood. 96:314-320.

3. Kaul, D.K., and Hebbel, R.P. 2000. Hypoxia/reoxygenation causes inflammatory response in trans-
}

genic sickle mice but not in normal mice. J. Clin. Invest. 106:411-420.

4. Francis, R.B.J., and Haywood, L.J. 1992. Elevated immunoreactive tumor necrosis factor and interleukin-1 in sickle cell disease. J. Natl. Med. Assoc. 84:611-615.

5. Oh, S.O., Ibe, B.O., Johnson, C., Kurantsin-Mills, J., and Raj, J.U. 1997. Platelet-activating factor in plasma of patients with sickle cell disease in steady state. J. Lab. Clin. Med. 130:191-196.

6. Klug, P.P., Kaye, N., and Jensen, W.N. 1982. Endothelial cell and vascular damage in the sickle cell disorders. Blood Cells. 8:175-184.

7. Sowemimo-Coker, S.O., Meiselman, H.J., and Francis, R.B., Jr. 1989. Increased circulating endothelial cells in sickle cell crisis. Am. J. Hematol. 31:263-265. 
8. Solovey, A., et al. 1997. Circulating activated endothelial cells in sickle cell anemia. N. Engl. J. Med. 337:1584-1590.

9. Platt, O.S. 2000. Sickle cell anemia as an inflammatory disease. J. Clin. Invest. 106:337-338.

10. Aslan, M., et al. 2001. Oxygen radical inhibition of nitric oxide-dependent vascular function in sickle cell disease. Proc. Natl. Acad. Sci. U. S. A. 98:15215-15220.

11. Conger, J.D., and Weil, J.V. 1995. Abnormal vascular function following ischemia-reperfusion injury. J. Investig. Med. 43:431-442.

12. Lonsdorfer, J., et al. 1983. Cardiorespiratory adjustments in chronic sickle cell anemia. Bull. Eur. Physiopathol. Respir. 19:339-344.

13. Rodgers, G.P., et al. 1990. Microcirculatory adaptations in sickle cell anemia: reactive hyperemia response. Am. J. Physiol. 258:H113-H120.

14. Lipowsky, H.H., Sheikh, N.U., and Katz, D.M. 1987. Intravital microscopy of capillary hemodynamics in sickle cell disease. J. Clin. Invest. 80:117-127.

15. Reiter, C.D., et al. 2002. Cell-free hemoglobin limits nitric oxide bioavailability in sickle-cell disease. Nat. Med. 8:1383-1389.

16. Belhassen, L., et al. 2001. Endothelial dysfunction in patients with sickle cell disease is related to selective impairment of shear stress-mediated vasodilation. Blood. 97:1584-1589.

17. Kaul, D.K., Fabry, M.E., Costantini, F., Rubin, E.M., and Nagel, R.L. 1995. In vivo demonstration of red cell-endothelial interaction, sickling and altered microvascular response to oxygen in the sickle transgenic mouse. J. Clin. Invest. 96:2845-2853.

18. Kaul, D.K., Liu, X.D., Fabry, M.E., and Nagel, R.L. 2000. Impaired nitric oxide-mediated vasodilation in transgenic sickle mouse. Am. J. Physiol. Heart Circ. Physiol. 278:H1799-H1806.

19. Nath, K.A., et al. 2000. Mechanisms of vascular instability in a transgenic mouse model of sickle cell disease. Am. J. Physiol. Regul. Integr. Comp. Physiol. 279:R1949-R1955.

20. Gladwin, M.T., et al. 2003. Divergent nitric oxide bioavailability in men and women with sickle cell disease. Circulation. 107:271-278.

21. Eberhardt, R.T., et al. 2003. Sickle cell anemia is associated with reduced nitric oxide bioactivity in peripheral conduit and resistance vessels. Am. J. Hematol. 74:104-111.

22. Steinberg, M.H., et al. 1997. Fetal hemoglobin in sickle cell anemia: determinants of response to hydroxyurea. Multicenter Study of Hydroxyurea. Blood. 89:1078-1088.

23. Brugnara, C., et al. 1996. Therapy with oral clotrim- azole induces inhibition of the Gardos channel and reduction of erythrocyte dehydration in patients with sickle cell disease. J. Clin. Invest. 97:1227-1234.

24. Fabry, M.E., et al. 2001. Second generation knockout sickle mice: the effect of HbF. Blood. 97:410-418.

25. Horiuchi, K., Osterhout, M.L., Kamma, H., Bekoe, N.A., and Hirokawa, K.J. 1995. Estimation of fetal hemoglobin levels in individual red cells via fluorescence image cytometry. Cytometry. 20:261-267.

26. Lim, S.K., et al. 1998. Increased susceptibility in $\mathrm{Hp}$ knockout mice during acute hemolysis. Blood. 92:1870-1877.

27. Turhan, A., Weiss, L.A., Mohandas, N., Coller, B.S., and Frenette, P.S. 2002. Primary role for adherent leukocytes in sickle cell vascular occlusion: a new paradigm. Proc. Natl. Acad. Sci. U.S. A. 99:3047-3051.

28. Schmedtje, J.F., Jr., Ji, Y.S., Liu, W.L., DuBois, R.N., and Runge, M.S. 1997. Hypoxia induces cyclooxygenase-2 via the NF-kappaB p65 transcription factor in human vascular endothelial cells. J. Biol. Chem. 272:601-608.

29. Okamoto, H., Ito, O., Roman, R.J., and Hudetz, A.G. 1998. Role of inducible nitric oxide synthase and cyclooxygenase- 2 in endotoxin-induced cerebral hyperemia. Stroke. 29:1209-1218.

30. Fiebig, E., Ley, K., and Arfors, K.E. 1991. Rapid leukocyte accumulation by "spontaneous" rolling and adhesion in the exteriorized rabbit mesentery. Int. J. Microcirc. Clin. Exp. 10:127-144.

31. Beckman, J.S., and Koppenol, W.H. 1996. Nitric oxide, superoxide, and peroxynitrite: the good, the bad, and ugly. Am. J. Physiol. 271:C1424-C1437.

32. Thomas, D.D., Espey, M.G., Vitek, M.P., Miranda, K.M., and Wink, D.A. 2002. Protein nitration is mediated by heme and free metals through Fentontype chemistry: an alternative to the NO/O2- reaction. Proc. Natl. Acad. Sci. U. S. A. 99:12691-12696.

33. Wu, G., et al. 2003. Hypoxia induces myocytedependent COX-2 regulation in endothelial cells: role of VEGF. Am. J. Physiol. Heart Circ. Physiol. 285:H2420-H2429.

34. Oltman, C.L., et al. 2003. Reactive oxygen species mediate arachidonic acid-induced dilation in porcine coronary microvessels. Am. J. Physiol. Heart Circ. Physiol. 285:H2309-H2315.

35. Nath, K.A., et al. 2001. Oxidative stress and induction of heme oxygenase- 1 in the kidney in sickle cell disease. Am. J. Pathol. 158:893-903.

36. Jison, M.L., et al. 2004. Blood mononuclear cell gene expression profiles characterize the oxidant, hemolytic, and inflammatory stress of sickle cell disease. Blood. 104:270-280.
37. Thengchaisri, N., and Kuo, L. 2003. Hydrogen peroxide induces endothelium-dependent and independent coronary arteriolar dilation: role of cyclooxygenase and potassium channels. Am.J. Physiol. Heart Circ. Physiol. 285:H2255-H2263.

38. Matoba, T., et al. 2000. Hydrogen peroxide is an endothelium-derived hyperpolarizing factor in mice. J. Clin. Invest. 106:1521-1530.

39. Denenberg, B.S., Criner, G., Jones, R., and Spann, J.F. 1983. Cardiac function in sickle cell anemia. Am.J. Cardiol. 51:1674-1678.

40. Kooy, N.W., and Lewis, S.J. 1996. Nitrotyrosine attenuates the hemodynamic effects of adrenoceptor agonists in vivo: relevance to the pathophysiology of peroxynitrite. Eur. J. Pharmacol. 310:155-161.

41. Kooy, N.W., and Lewis, S.J. 1996. The peroxynitrite product 3-nitro-L-tyrosine attenuates the hemodynamic responses to angiotensin II in vivo. Eur. J. Pharmacol. 315:165-170.

42. Hatch, F.E., Crowe, L.R., Miles, D.E., Young, J.P., and Portner, M.E. 1989. Altered vascular reactivity in sickle hemoglobinopathy. A possible protective factor from hypertension. Am. J. Hypertens. 2:2-8.

43. Paszty, C., et al. 1997. Transgenic knockout mice with exclusively human sickle hemoglobin and sickle cell disease. Science. 278:876-878.

44. Paszty, C., et al. 1995. Lethal alpha-thalassaemia created by gene targeting in mice and its genetic rescue. Nat. Genet. 11:33-39.

45. Shehee, W.R., Oliver, P., and Smithies, O. 1993. Lethal thalassemia after insertional disruption of the mouse major adult beta-globin gene. Proc. Natl. Acad. Sci. U. S. A. 90:3177-3181.

46. Gilman, J. 1995. Developmental changes of human G $\gamma$ and ${ }^{A} \gamma$ and mouse embryonic $\varepsilon^{\gamma 1}, \varepsilon^{\gamma / 2}$ and $\beta \eta$ in transgenic mice with HS4-G $\gamma_{-}{ }^{\mathrm{A}} \gamma$ [abstract]. Blood. 86:648a.

47. Baez, S. 1973. An open cremaster muscle preparation for the study of blood vessels by in vivo microscopy. Microvasc. Res. 5:384-394.

48. Silva, J., and Intaglietta, M. 1974. The correlation of photometric signals derived from in vivo red blood cell flow in microvessels. Microvasc. Res. 7:156-169.

49. Wayland, H., and Johnson, P.C. 1967. Erythrocyte velocity measurement in microvessels by a two-slit photometric method. J. Appl. Physiol. 22:333-337.

50. Baker, M., and Wayland, H. 1974. On-line volume flow rate and velocity profile measurement for blood in microvessels. Microvasc. Res. 7:131-143.

51. Seki, J., and Lipowsky, H.H. 1989. In vivo and in vitro measurements of red cell velocity under epifluorescence microscopy. Microvasc. Res. 38:110-124. 